\title{
HANTEER DIE \\ STUDENTVERPLEEGKUNDIGE \\ AS WAARDIGE MENS
}

\section{A.W. BEEKMAN \\ Dosent, Randse Afrikaanse Universiteit}

\section{SUMMARY}

In recent studies and research there was some evidence that students felt that they are not treated as unique human beings with individuality, dignity and worthiness. Based on the literature this problem can be solved through accompaniment and a relationship of insight, trust and discipline between the ward sister or matron and the student.

\section{INLEIDING EN PROBLEEM- STELLING}

In haar werk Begeleiding in die verpleegkunde kom Kotzé tot die slotsom dat die studentverpleegkundige as mens raakgesien en aanvaar moet word. Sy sê: Die verpleegkundige moet immer poog om die menslikheid in die student raak te sien haar in haar moontlikhede en feilbaarheid te aanvaar en menslik met haar te handel. Kotzé gaan ook verder en sê dat agting vir die student se waardigheid nie net in eerbiediging van haar as mens lê nie, maar ook in dié mate waarin die verpleegkundige die student se intimiteit bewaar en dit wat sy vanuit die vertrouensposisie van die student te wete mag kom met niemand bespreek nie. (2, pp. 247,249)

Aan hierdie opgaaf aan die verpleegkundige om die student as mens met waardigheid te sien, word egter nie altyd in die verpleegpraktyk voldoen nie. Die studentverpleegkundige ervaar dikwels dat sy nie gesien word as ' $n$ individu nie, maar as een van baie ander studente.

In navorsing gedoen deur die Subkomitee op Verpleging in 1981, word belangrike opmerkings gemaak wat genoemde probleem uitlig. In die houdingsopname toon $71,16 \%$ studente aan dat verpleging nie voldoen aan hulle verwagtinge nie. Benewens status van die verpleegster en werksomstandighede, voel studente dat hul eie verwagtinge verydel is. Die volgende word in hierdie opname uitgelig:

die student word nie as individu gesien nie

die student is net ' $n$ werkesel wat soos ' $n$ bediende en ' $n$ kind behandel word . . . (4,p16)

Redes waarom bedanking oorweeg is en waarop $33,76 \%$ studente Ja geantwoord het is, onder andere, swak interpersoonlike verhoudinge soos:

* die saalsuster behandel die student soos 'n kind

* geen saak is vertroulik as dit met die matrone bespreek is nie $(4, \mathrm{p} 6)$

Dit skyn asof hierdie probleem nie net in Suid-Afrika voorkom nie, maar universeel is. Dale, as student in Brittanje, sê byvoorbeeld:

As a first year student I am sick of the ever present distance imposed between the learners and the trained staff - please judge me as a person, and not just another PTS . . (3.1, p9)

In die lig van hierdie gegewens blyk dit dat daar wel 'n leemte in die erkenning en eerbiediging van die studentverpleegkundige se menswaardigheid is. Dit sal dan om hierdie rede ter sake wees om ondersoek in te stel na en te besin oor die aspek menswaardigheid.

\section{MENSWAARDIGHEID}

Vanuit die Christelike denke word dit allerweë aanvaar dat God die mens as skepsel na sy beeld en gelykenis geskape het. Hierdie waardigheid (dié van God self) wat aan die mens toevertrou is, word deur
Landman en Roos verklaar as 'n omvattende beeld van 'n persoon met sekere waardes. In wese beteken die begrip menswaardigheid dus dat elke persoon met waardigheid beklee is omdat hy mens is en impliseer dit dat elke mens sekere waardes het waarin hy glo, waarmee hy hom bemoei en waarna hy streef. Die manier waarop hy egter na hierdie waardes streef is enig en daarom kan tereg gesê word dat die mens uniek is. $(1, \mathrm{p} 27)$

Om 'n mens as uniek te sien beteken dat jy hom sal sien as ' $n$ individu met 'n persoonlikheid, karaktertrekke en kenmerke wat eie is aan hom en wat anders is as dié van alle ander mense. Jy sal ook besef dat hy eie waardes het en voortdurend besig is om nuwe waardes te verwerf.

\section{MENSWAARDIGHEID IN DIE VERPLEEGPRAKTYK}

Hierdie fundamentele aspekte van menswaardigheid kan in die praktyk van die verpleegkundige ingebou word in die begeleidingsverhouding. Hierdie verhouding is in wese intermenslik en word gekenmerk deur dialoog tussen twee persone, in dié geval, die suster/matrone en student.

In hierdie begeleidingsverhouding is dit eerstens belangrik dat die verpleegkundige (hetsy die saalsuster, zonematrone of matrone) die student moet ken en begryp. Dit sluit in kennis met betrekking tot die student se agtergrond, vorige 
werksrekord, huidige prestasie en vordering asook haar belangstellings, ideale en behoeftes of probleme. Op grond hiervan is dit moontlik om die student se vermoëns (moontlikhede en/of beperkings) raak te sien en te waardeer, wat sal voorkom dat sy oorof onderskat word. Dale sê byvoorbeeld in haar noodkreet:

- please judge me as a person, and not just another PTS, because if I'm treated as an idiot, I may start to act like one! (3.1, $\mathrm{p} 9)$

Cathy Campbell gaan verder en sê: $A$ common complaint is that until something goes wrong we are treated as being incapable of carrying out the simplest task". $(3.2, \mathrm{p} 14)$

Hierdie onder- of oorskatting is nie net 'n gevolg van gebrekkige kennis en/of begrip nie, maar dui ook op te min vertroue in die student. Kotzé sê dat aanvaarding uit kennis van die student groei en dat daar sonder begrip in die ware sin van die woord nie van vertroue gepraat kan word nie. 'n Vertrouensverhouding waarin die suster bereidwilligheid toon, na die student luister en haar vermoëns na waarde skat, vir haar beskikbaar is en haar intieme mislukkings en swakhede as geheim bewaar, spreek van agting vir die student se menswaardigheid. (2, pp 246,247)

So 'n verhouding impliseer allermins 'n houding van familiaritiet, maar wel dat afstand ook in die sin van gesagshandhawing behou word. Hierdie gesag is nie baseer op skeiding en ontoeganklikheid nie, maar is meer gerig op die meerdere kennis van die suster/matrone teenoor dié van die student. $(1, \mathrm{p} 35 ; 2$, p247)

\section{SLOT}

Samevattend blyk dit dus dat mens- waardigheid tot uiting kom in die erkenning van uniekheid en dit sluit die mens se individualiteit, andersheid en waardeverwesenliking in.

In die praktyk word uniekheid verwerklik deurdat die suster/matrone kennis en begrip van die student het sodat daar wedersydse vertroue is, maar ook deurdat daar gesagshandhawing is ten einde vir die student ' $n$ veilige en geborge onderrig- en opleidingsmilieu te skep waarin sy tot haar volle potensiaal kan kom.

\section{BIBLIOGRAFIE}

1. Beekman, A W Dosente se Mensbeeld van die Verpleeg student. Ongepubliseerde skripsie. Randse Afrikaanse Universiteit. 1981

2. Kotzé, W J Begeleiding in die Verpleegkunde Suid Afrikaanse Verpleegstersvereniging. Pretoria. 1979

3. Nursing Mirror

3.1 Desember 1976

3.2 Vol 152 No 9 Februarie 198

4. Verslag van die Subkomitee op Verpleging - Byloag $G$ Ongepubliseer. 1981

\section{COMPLETED RESEARCH VOLTOOIDE NAVORSING}

\section{'N ONDERSOEK NA DIE BEHOEFTES EN VERSORGING VAN BEJAARDES TE WESTDENE}

\author{
Johanna Maria Adriana Pretorius \\ Departement Verpleegkunde, Universiteit van die \\ Oranje-Vrystaat \\ M.Soc.Sc.
}

Met die toename in die aantal bejaardes het die aanvraag en behoefte na verbeterde gesondheidsdienste vir dié lede van die samelewing vermeerder, en derhalwe word meer aandag gegee aan die bepaling en bevrediging van dié behoeftes van die bejaarde deur lede van die gesondheidspan. Die verouderingsproses is 'n natuurlike fase in die lewe van die mens, maar bring 'n afname in lewenskrag en gesondheid mee. Toenemende afhanklikheid is gewoonlik die gevolg en die hulp en bystand van die gesondheidspan kan dan onontbeerlik word. Die bejaarde is ook meer aangewys om op sy eie of saam met ander bejaardes te woon weens die verstedeliking en veranderde gesinstruktuur. In Suid-Afrika is bejaardesorg meer gerig op inrigtingsversorging van hulpbehoewende bejaardes, met die gevolg dat ander aspekte van dienslewering agterweë bly. Die ideale uitgangspunt van bejaardesorg moet wees om bejaardes te help om so lank as moontlik in die gemeenskap te funksioneer. Probleme soos behuising, gesondheid en voeding van die bejaarde word oorbeklemtoon, terwyl die voorreg van die bejaarde om 'n hoë ouderdom te benut en te geniet geïgnoreer word.

In Westdene, 'n voorstad van Bloemfontein, is ' $n$ groot aantal bejaardes woonagtig wat nog selfversorgend en selfonderhoudend is. Omdat hulle meesal op hulself aangewese is en hulle in huise en woonstelle bly, is besluit om 'n ondersoek te loods om vas te stel watter gemeenskapsdienste daar aangebied word, watter behoeftes by hulle bestaan en of die dienste voldoende is al dan nie. Daar is ook gepoog om vas te stel waarom die bejaardes nie van die beskikbare dienste gebruik maak nie.

Volgens die navorsingsbevindings blyk dit dat die bejaardes van Westdene ' $n$ redelike onafhanklike, selfvoorsienende groep is. Behoeftes wat wel aandag behoort te geniet, is bekamping van eensaamheid by die bejaarde en voorsiening van vervoer.

Die oprigting van 'n dienssentrum behoort ernstige aandag te ontvang, omdat die bejaardes van Westdene 'n ouerwordende bevolking is en genoemde behoeftes dus kan vermeerder.

Volgens die navorsingsbevindinge word daar goed in die behoeftes van die bejaardes te Westdene voorsien en is daar dus net enkele aanbevelings in verband met verbetering van dienste gemaak. 